\title{
Influence of Ozonation and Storage of Wheat Grains on Chemical Composition and Rheological Properties
}

\author{
Saad, S.M.M. ; Abd-Elrahman, A.A." and El-Desouky, T.A.**; Sarhan, A.F.M..* \\ * Dept. of Agric. Biochemistry, Faculty of Agric., Benha Univ., Egypt. \\ ** Food Toxicology and Contaminants Dept., National Research Center. \\ Corresponding author: Ashraf_Elmorshedy@ hotmail.com
}

\begin{abstract}
Ozonation of wheat grains is considered as a quick and easy process that could be realized during the storage. The ozone is in direct contact with the grain and may modify the properties of the wheat. In the present study the effect of ozonation local wheat (LW) and red Roman wheat (RRW) at $80 \mathrm{ppm}$ with exposure time 30 and 60 min before storage for 3 and 6 months on chemical composition, rheological properties of wheat flour and content of amino acids were carried out. The obtained results indicated that ozonated wheat grains did not significantly alter the chemical composition of LW and RRW after ozonation. On the other hand stability and resistance of dough were increased with ozonation for $60 \mathrm{~min}$ in comparison with control sample. In general, the results indicated that increments in the amount of amino acids with increasing time of exposure to ozone gas.
\end{abstract}

Keywords: Ozonation, Local wheat, Red Roman Wheat and amino acids.

\section{Introduction}

Around the world, there has been an over-reliance on the use of synthetic pesticides like methyl bromide and phosphine in stored grain protection that has produced many important problems such as development of resistance by stored product pests, concerns with the environment (ozone depletion), and non-desirable side effects on nontarget organisms such as humans and animals. These side effects have raised public concern about the routine use and safety of pesticides including the phase out of methyl bromide under the Montreal Protocol (Kells et al., 2001). Therefore, there is an increasing demand worldwide for the use of alternatives for pest control such as temperature extremes, modified atmospheres, heat treatment of empty structures, physical exclusion, non-chemical protectants, biological controls, and the application of ozone to control stored product pests. Ozone gas is a powerful oxidant capable of reaction with numerous chemical groups. Ozone gas is a powerful oxidising agent with a demonstrated ability to reduce populations of bacteria and fungi in a diversity of use situations (Kim et al., 1999). Ozone gas can inhibit growth of Aspergillus flavus and degradation aflatoxin $\mathrm{B}_{1}$ in wheat grains during storage (El-Desouky et al., 2012a,b). This powerful oxidant makes it possible to destroy many microorganisms and organic molecules. Ozone was approved as a generally recognized as safe (GRAS) in 1997 by food and drug administration (FDA), this reagent is more and more used for food treatment as grain (Guzel-Seydim et al., 2004). Ozone offers unique advantages for food grain processing with minimal or desired effects on the physicochemical properties. Hence ozone treatment is a potential greener alternative to conventional fumigants. Ozone gas is biologically safe and does not produce any secondary compounds that may cause toxicity (ElDesouky et al., 2017). Ozonation of wheat grain is a quick and easy process that could be realized during the storage. The ozone is in direct contact with the grain and modifies immediately the properties of the wheat. However, the ozone has to go through the pericarp and the seed coat to reach the endosperm, which represents the greater proportion of the short grade flour. Therefore expected that not all of the ozone will penetrate the endosperm and the flour that follows will have specific characteristics. The main aims of the present is in a trial to study are to evaluation of evaluate the ozonation effect on chemical composition of wheat grains and rheological properties of dough.

\section{Materials and Methods}

\section{Materials:}

Red Roman wheat (RRW) samples were obtained from the General Company for Silos and Storage (GCSS), Giza Governorate, Egypt. Local wheat (LW) samples were obtained from the General Shoun of Wheat.

\subsection{Production of ozone gas:}

Ozone gas was produced from air using ozone generator Model OZO 6 VTTL OZO Max Ltd, Shefford, Quebec Canada. (OZO MAX LTD, shefford, Quebec, Canada) from purified extra dry oxygen feed gas. The amount of output from ozone was controlled by a monitor- controller having a plugin sensor on board which is changed for different ranges of ozone concentration and a belt pan in the monitor-controller allows controlling the concentration in a selected range.

\section{Methods:}

\subsection{Wheat flour:}

The wheat samples were milled using barabender DUISBUG (type: 279002) available at Department of 
Bread and Dough, Food Technology Research Institute, Agricultural Research Center, Giza, Egypt. Final obtained wheat flour was $72 \%$ extraction.

\subsection{Samples treatment:}

Wheat grains were transferred into a $1000 \mathrm{ml}$ flask and the sample flask was plugged with a silicone stopper with 2 holes in it. One hole was for the ozone line and the other was for tubing connected to the ozone destruct unit. The wheat grain was treated at $80 \mathrm{ppm}$ for 30 and $60 \mathrm{~min}$ at room temperature.

\subsection{Determination of ash, crude fat, crude protein:}

Ash, crude fat content and crude protein of wheat samples were determined according to AOAC official methods (AOAC, 2000).

\subsection{Total carbohydrates:}

Total carbohydrate of wheat grain was calculated from the equations described in Samati and Rajagopal (1996):

Total Carbohydrates $(\%)=100-(\%$ protein $+\%$ fat $+\%$ ash)

\subsection{Rheological properties:}

2.5.1. Farinograph test:

The samples were tested by Brabender farinograph APH model No 177511 Germany) was used to determined water absorption (\%), arrival time (min), dough development time ( $\mathrm{min})$, dough stability ( $\mathrm{min}$ ), mixing tolerance index and degree of weakening. Three hundreds grams of tested flour samples were placed in the bowel of the apparatus and sufficient water was added so that the consistency of the dough reached the optimum form when the mixing curve centered on the 500 Brabendar units (B.U.) at the point of maximum development. Different parameters were obtained from the farinograms i.e. (Water absorption (\%), arrival time ( $\mathrm{min})$, dough development time (min), dough stability (min), mixing tolerance index and weakening of dough (B.U.)

\subsubsection{Extensograph test:}

Extensograph model No: 178525 was used for determination the parameters of extensibility (E) $(\mathrm{mm})$, resistance to extension (R) (B.U), proportional number $(\mathrm{R} / \mathrm{E})$ and dough energy $\left(\mathrm{cm}^{2}\right)$. Extensograph test was carried out as follows:

A normal run of the farinograph was mad in order to estimate the water absorption capacity of the flour. The dough prepared from three hundreds grams flour and six grams sodium chloride dissolved in the quantity of water (estimated by farinogeaph). The produced dough was mixed for one minute after which a sufficient salt solution was added to give a consistency of 500 Brabender line (in farinogeaph test), after $5 \mathrm{~min}$ of rest ,mixing was resumed and continued until reached the full development time of the farinogram. The dough was removed from the mixer and cut into two portions, each $150 \mathrm{~g}$. The dough was rounded in the extensograph rounder. The dough ball was then carefully centered on the shaping unit and rolled into a cylindrical test pieces, this was ten clamped in a lightly greased dough holder. The tested piece was stored in humidified chamber for $45 \mathrm{~min}$ from the shaping operation, the stretching hook was started and stopped when the test piece was broken; dough was removed after the first test, reshaped, allowed a rest period of $45 \mathrm{~min}$ and then was stretched again. By repeating such procedure, the dough was tested at 45, 90 and $135 \mathrm{~min}$.

For evaluating the results of the extensograph test; the extensogram of the test period at 45; 90 and 135 min were used to measure the follwing data. dough extensibility (E) (mm); dough resistance to extension (R) (B.U.) and proportional number (R/E).

\subsection{Amino acids evaluation:}

Amino acids contents in RRW and LW after and before ozonation at $80 \mathrm{ppm}$ with exposure time 30 and $60 \mathrm{~min}$ were determined to illustrate the effect of these treatments on the profile of the amino acid content. The determination of amino acid contents were carried out according to Moore et al. (1958) using Bechman Amino Acid Analyzer Model 121.

\section{Results and Discussion}

1. Effect of ozone gas on chemical composition of local wheat (LW) and Red Roman Wheat (RRW):

The data presented in Table (1) show the chemical composition of $\mathrm{LW}$. The results show that the control sample of wheat grain contained 12.6. \% moisture, 2.4 ash, $1.8 \%$ fat, $11.9 \%$ protein, $2.3 \%$ crude fiber and $81.6 \%$ total carbohydrates. The obtained results are in agreement with those reported by (Selim, 2000 and Hussein et al., 2010). The achieved results indicated that ozonated wheat grain did not significantly alter the chemical of the wheat flour. The accomplished results arein agreement with other studies (Ibanoglu, 2002; Paul 2005 and Sandhu et al., 2011). The obtained results of moisture content were in agreement with values obtained by Ibanoglu (2002) who reported that the ozonated tempering had no effect on moisture content. The protein values of ozonated and non-ozonated wheat ranged from 11.9 to $12.3 \%$. These results were in agreement with that reported by Ibanoglu (2002) who concluded that the ozonated wheat grains did not cause any chemical or physical changes. The effect of ozone is considered to be restricted to the outer surface of exposed material. Thus, even though flour is exposed to ozone, only the functional groups exposed on the surface of the flour particle would be subjected to oxidation by ozone. Also, flour particles on the exposed surface of a flour container or silo would be more subject to ozone oxidation than particles in the interior of the silo or container (Sandhu et al., 2012). The ozone is indirect contact with the grain and modifies immediately the 
properties of the wheat. However, the ozone has to go through the pericarp and the seed coat to reach Therefore expected that not all of the ozone will penetrate the endosperm and the flour that follows will have specific characteristics (Dubois et al., 2006)

Table 1. Chemical composition of local wheat (LW) after ozonation at $80 \mathrm{ppm}$. (Dry weight basis)

\begin{tabular}{lcccccc}
\hline \multirow{2}{*}{ Treatment } & \multicolumn{6}{c}{ Chemical composition of local wheat } \\
\cline { 2 - 7 } & $\begin{array}{c}\text { Moisture } \\
(\%)\end{array}$ & $\begin{array}{c}\text { Ash } \\
(\%)\end{array}$ & $\begin{array}{c}\text { Fat } \\
(\%)\end{array}$ & Protein $(\%)$ & $\begin{array}{c}\text { Fiber } \\
(\%)\end{array}$ & $\begin{array}{c}\text { Carbo- } \\
\text { hydrates* } \\
(\%)\end{array}$ \\
\hline Control & 12.6 & 2.4 & 1.8 & 11.9 & 2.3 & 81.6 \\
\hline ozonation for 30min & 12.4 & 2.4 & 1.8 & 12.0 & 2.3 & 81.5 \\
\hline ozonation for 60min & 12.3 & 2.4 & 1.8 & 12.3 & 2.3 & 81.2 \\
\hline
\end{tabular}

*Carbohydrate by difference.

The data presented in Table (2) show the chemical composition of RRW. The results show that the control sample of wheat grain was contained $12.5 \%$ moisture, $2.3 \%$ ash, 1 . $\%$ fat, $11.7 \%$ protein, $2.5 \%$ crude fiber and $81.8 \%$ total carbohydrates. Also the results indicate that no significant effect on chemical composition of RRW after ozonation at $80 \mathrm{ppm}$ for 30 and $60 \mathrm{~min}$. The obtained results are in agreement with that reported by Ibanoglu (2002) and Sandhu et al. (2012).

Table 2. Chemical composition of Red Roman Wheat (RRW) after ozonation at $80 \mathrm{ppm}$. (dry weight basis)

\begin{tabular}{|c|c|c|c|c|c|c|}
\hline \multirow{2}{*}{$\begin{array}{l}\text { Treatment } \\
\text { Wheat control }\end{array}$} & \multicolumn{6}{|c|}{ Chemical composition of local wheat } \\
\hline & $\begin{array}{c}\text { Moisture } \\
(\%)\end{array}$ & $\begin{array}{l}\text { Ash } \\
(\%)\end{array}$ & $\begin{array}{l}\text { Fat } \\
(\%)\end{array}$ & Protein $(\%)$ & $\begin{array}{c}\text { Fiber } \\
(\%)\end{array}$ & $\begin{array}{c}\text { Carbo-hydrates* } \\
(\%)\end{array}$ \\
\hline Control & 12.5 & 2.3 & 1.7 & 11.7 & 2.5 & 81.8 \\
\hline ozonation for $30 \mathrm{~min}$ & 12.5 & 2.3 & 1.8 & 11.7 & 2.3 & 81.9 \\
\hline ozonation for $60 \mathrm{~min}$ & 12.3 & 2.3 & 1.8 & 11.9 & 2.3 & 81.7 \\
\hline
\end{tabular}

*Carbohydrate by difference.

From the obtained results (Tables 1 and 2), it has concluded that there are slight differentiation between the chemical composition of local wheat (LW) and red Roman wheat (RRW). And also, the ozonation treatment had no or did not effect on both types of wheat.

\subsection{Effect of ozone treatment on farinogram parameters:}

Data in Tables (3 and 4) show the farinograph parameters from wheat flour dough (72\% extraction) after ozonation wheat grain at $80 \mathrm{ppm}$, i.e. water absorption, arrival time, dough development time, dough stability and dough weakening. In case LW the results indicated that the water absorption ranged from 64 to $66 \%$ in control sample and different treatment. But arrival time was 1 . to $2.5 \mathrm{~min}$ with sample control and treatment.. While there were increments in mixing tolerance index and degree of weakening. RRW grains ozonated at $80 \mathrm{ppm}$ for 30 and $60 \mathrm{~min}$ the water absorption ranged from 62 to $65 \%$ in control sample and treatment as shown in Table (4), respectively. Arrival time was increased to $3.5 \mathrm{~min}$ with ozonation sample and stored for 3 months compared with control sample $(2.5 \mathrm{~min})$. Development time was $2.5 \mathrm{~min}$ in control samples and ozonated for 30 and $60 \mathrm{~min}$ stored for 6 months. The obtained results are in agreement with those obtained by (Ibanoglu, 2002 and Sandhu et al., 2011). High dose and short exposure to ozone might improve dough strength by promoting disulfide bond formation. Unextractable polymeric proteins have been positively correlated with dough strength
(Gupta et al., 1993 and El-Desouky et al., 2013). Ozone treatment increased the amount of unextractable polymeric proteins. An increase in unextractable polymeric proteins would improve dough strength and thus increase the dough development time (Sandhu et al., 2011). Amino acids could be oxidized by ozone. In fact, tyrosine is oxidised to dityrosine by ozone. Takasaki et al. (2005) suggested that dityrosine could be a new kind of stabilizing cross-link in the wheat gluten structure in addition to disulphide bonds. On the other hand Mendez et al. (2003) reported that ozone treatment does not significantly change the bread-making properties of hard wheat, including tolerance of the dough to overmixing, absorption of water, dough weight, and proof height. Hoseney (1994) reported that the formation of new disulphide bonds in the presence of an oxidizing agent would increase the strength of the dough with high stability and low degree of softening. Similarly, any cleavage of the disulphide bond would result in the weakness of the dough giving low stability and high degree of softening. So the storage of grains in ozone rich atmospheres does not influence the rheological properties of grains. For example Mendez et. al. (2003) investigated the efficacy of ozone to control pests for stored wheat and rice. They reported that ozone treatment does not significantly change the bread-making properties of hard wheat, including tolerance of the dough to over mixing, absorption of water, dough weight, and proof height. 
Table 3. Farinogram parameters of local wheat (LW) ozonated at 80ppm which stored for 3 and 6 months.

\begin{tabular}{|c|c|c|c|c|c|c|c|}
\hline Farinogram parameters & Control & $\begin{array}{l}\text { LW stored } \\
\text { for } 3 \text { months }\end{array}$ & $\begin{array}{l}\text { LW stored } \\
\text { for } 6 \text { months }\end{array}$ & $\begin{array}{l}\text { LW stored for } 3 \\
\text { months and } \\
\text { ozonation for } 30 \\
\text { min }\end{array}$ & $\begin{array}{l}\text { LW stored for } 3 \\
\text { months and } \\
\text { ozonation for } 60 \\
\text { min }\end{array}$ & $\begin{array}{l}\text { LW stored for } 6 \\
\text { months and } \\
\text { ozonation for } 30 \\
\text { min }\end{array}$ & $\begin{array}{l}\text { LW stored for } 6 \\
\text { months and } \\
\text { ozonation for } 60 \\
\text { min }\end{array}$ \\
\hline Water absorption (\%) & 64 & 66 & 65 & 66 & 65 & 65 & 64 \\
\hline Arrival time (min) & 2.5 & 2.0 & 1.5 & 1.0 & 1.5 & 2.0 & 1.0 \\
\hline Development time (min) & 3.0 & 2.5 & 2.0 & 1.5 & 2.5 & 2.5 & 1.5 \\
\hline Stability time (min) & 9.5 & 14.50 & 9.5 & 4.5 & 5.5 & 4.0 & 12.0 \\
\hline Mixing tolerance index (B.U) & $\mathbf{1 0}$ & 20 & 40 & 60 & 50 & 60 & 60 \\
\hline Degree of weakening (B.U) & 60 & 30 & 70 & 10 & 40 & 60 & 50 \\
\hline
\end{tabular}

Table 4. Farinogram parameters of Red Roman Wheat (RRW) ozonated at 80ppm which stored for 3 and 6 months.

\begin{tabular}{|c|c|c|c|c|c|c|c|}
\hline Farinogram parameters & Control & $\begin{array}{l}\text { RRW } \\
\text { stored for } 3 \\
\text { months }\end{array}$ & $\begin{array}{l}\text { RRW } \\
\text { stored for } \\
6 \text { months }\end{array}$ & $\begin{array}{l}\text { RRW stored for } 3 \\
\text { months and } \\
\text { ozonation for } \mathbf{3 0} \\
\text { min }\end{array}$ & $\begin{array}{l}\text { RRW stored for } 3 \\
\text { months and } \\
\text { ozonation for } 60 \\
\text { min }\end{array}$ & $\begin{array}{l}\text { RRW stored for } \\
6 \text { months and } \\
\text { ozonation for } \\
\mathbf{3 0} \text { min }\end{array}$ & $\begin{array}{l}\text { RRW stored for } \\
6 \text { months and } \\
\text { ozonation for } \\
60 \text { min }\end{array}$ \\
\hline Water absorption (\%) & 62 & 64 & 62 & 64 & 65 & 65 & 64 \\
\hline Arrival time (min) & 1.5 & 1.0 & 2.0 & 2.5 & 2.5 & 2.0 & 2.0 \\
\hline Development time( min) & 2.5 & 2.0 & 2.5 & 3.5 & 3.0 & 2.5 & 2.5 \\
\hline Stability time (min) & 11.5 & 10.0 & 11.0 & 11.5 & $\mathbf{1 0 . 5}$ & 3.0 & 3.0 \\
\hline Mixing tolerance index (B.U) & 10 & 20 & 20 & 20 & 20 & 70 & 50 \\
\hline Degree of weakening (B.U) & $\mathbf{5 0}$ & 80 & 50 & 60 & 50 & 70 & 70 \\
\hline
\end{tabular}




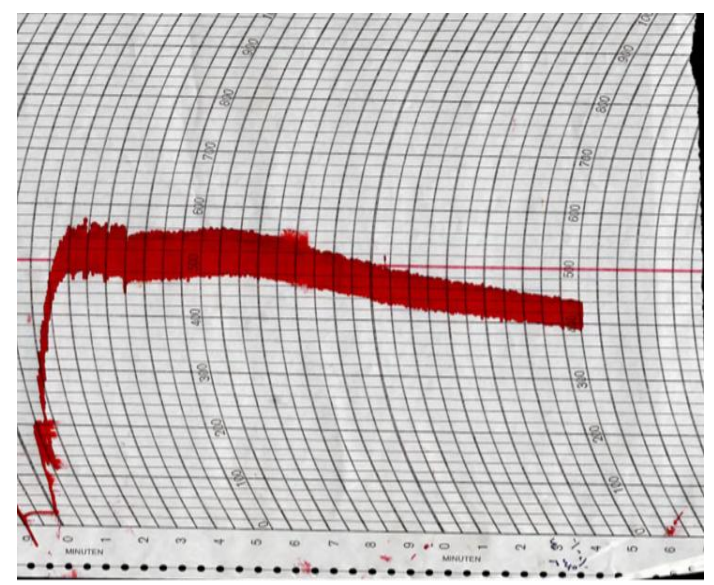

Fig (1) The farinogram in control sample of RRW.

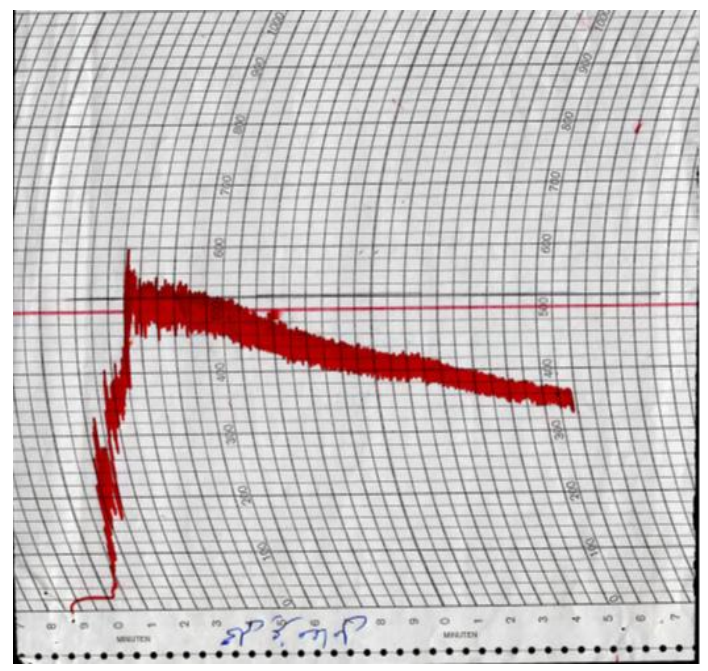

Fig (3) The farinogram in control sample of LW.

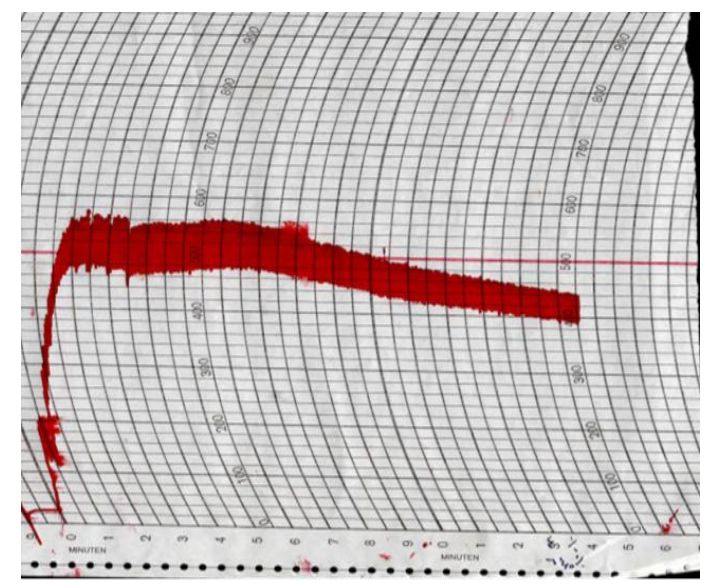

Fig (2)The farinogram in RRW sample ozonated at $80 \mathrm{ppm}$ for $60 \mathrm{~min}$

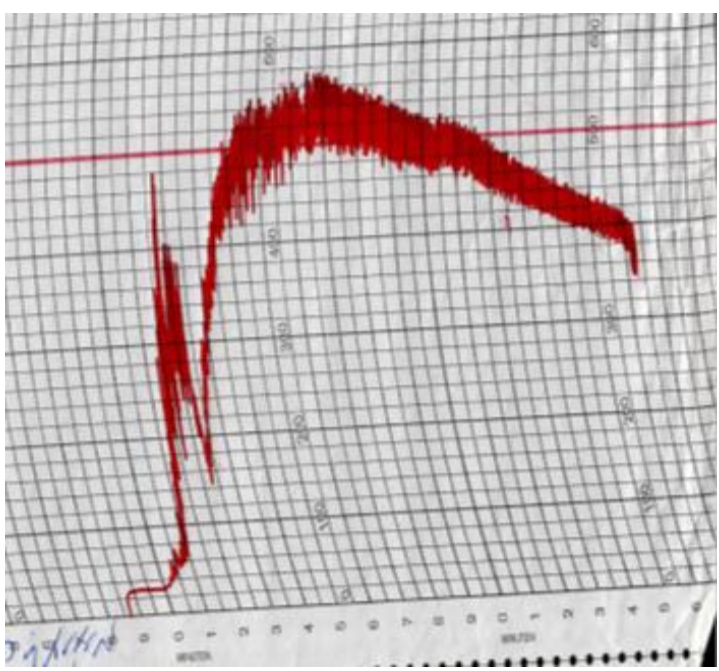

Fig (4)The farinogram in LW sample ozonated at $80 \mathrm{ppm}$ for $60 \mathrm{~min}$ 


\subsection{Effect of ozone treatment on extensograph parameters:}

Results presented in Tables (5) showed the effect of ozonation at $80 \mathrm{ppm}$ for 30 and $60 \mathrm{~min}$ with storage period 3 and 6 months on extensograph parameters for both types of wheat (LWand RRW). Extensibility values in control LW were 560, 440 and $420 \mathrm{~mm}$ after fermentation for 45, 90 and $135 \mathrm{~min}$, respectively. The results indicated that increments in extensibility after ozonation to 620,700 and $440 \mathrm{~mm}$ with LW stored 3 and 6 months, respectively treated by ozone gas for 30 min .In addition the resistance increased to 580 B.U., with samples stored for 6 months after ozonated for 60 min comparing with control which equaled to 470 B.U. The accomplished results are agreement with those obtained by (Naito, 1990) who found ozonation of soft to medium wheat flour caused an increase in the resistance to extension of wheat flours and a decrease in extensibility. Ozonation of wheat grain led to flour with higher force and tenacity and lower extensibility than the control. It might be a competition between a protein polymerization/de-polymerization probably may be due to oxidation by ozone Violleau et al. (2012). Whereas the intermolecular SH groups of wheat flour were decreased by about $30 \%$ by ozone treatment at $50 \mathrm{ppm}$ for $1 \mathrm{hr}$, but intermolecular S-S bonds were increased by about $5 \%$ by the same treatment. (Dubois et al., 2006).

Results in Table (6) showed the effect of ozonation at $80 \mathrm{ppm}$ for 30 and $6 \mathrm{~min}$ with storage period 3 and 6 months on exensograph parameters for RRW. Extensibility values forcontrol were 490, 400 and 380 $\mathrm{mm}$ after three period fermentation i.e. 45,90 and 135 min, respectively. The obtained results indicated there were decrements in extensibility as the period fermentation increased in control sample. The values of extensibility were increased (590 and $640 \mathrm{~mm}$ ) after the storage for 3 and 6 months, respectively in untreated samples also this parameter was increased in case of treated sample with ozonaion ( $80 \mathrm{ppm})$ for 30 min and stored for three months which reached to 640 $\mathrm{mm}$. On the other hands, RRW samples stored for 3, 6, 6 months andozonated for $60,30,60 \mathrm{in}$, the extensibility values were decreased, these values were $380,400,420 \mathrm{~mm}$ for $45 \mathrm{mn}$ period fermentation.

The obtained results there were decrements in extensibility as the period of fermentation decreased (90, $135 \mathrm{~min})$, these results had the same trend of control sample.

The obtained results cited in Table (6) indicated that the resistance of control sample equaled to 470B.U. While these values decreased and then increased i.e. the resistance parameter had the same trend of extensibility parameter, respectively.

The obtained are in agreement with that reported by Hoseney (1994), Takasaki et al. (2005) and Sandhu et al. (2011).

From the results in Tables ( 3 and 5) it concluded that the application of ozonation treatment for local wheat at $80 \mathrm{ppm}$ for $30,60 \mathrm{~min}$ and storage period for 6 months gave the best for farinograph results and extensograph parameters.

On the other hand, from the Tables (4 and 6) it has been observed that the application of ozonation treatment for red Roman wheat at $80 \mathrm{ppm}$ for 30 and $60 \mathrm{~min}$ and storage period for three months gave the best results of farinograph and extensograph parameters.

Table 5. Extensogram parameters of LW ozonated at $80 \mathrm{ppm}$.

\begin{tabular}{|c|c|c|c|c|c|}
\hline \multirow[t]{2}{*}{ Treatment samples } & \multicolumn{3}{|c|}{$\begin{array}{c}\text { Extensibility (E) } \\
\text { (m.m) after three period } \\
\text { fermentation }\end{array}$} & \multirow{2}{*}{$\begin{array}{l}\text { Resistance to } \\
\text { extension (R) } \\
\quad \text { (B.U.): }\end{array}$} & \multirow[t]{2}{*}{$\begin{array}{r}\text { Proportional } \\
\text { number }(\mathrm{R} / \mathrm{E})\end{array}$} \\
\hline & $45 \mathrm{~min}$ & $90 \mathrm{~min}$ & $135 \mathrm{~min}$ & & \\
\hline Control & 560 & 440 & 420 & 470 & 2.5 \\
\hline LW stored for 3 months & 360 & 300 & 260 & 315 & 2.5 \\
\hline LW stored for 6 months & 300 & 240 & 180 & 245 & 1.8 \\
\hline $\begin{array}{l}\text { LW stored for } 3 \text { months and } \\
\text { ozonation for } 30 \mathrm{~min}\end{array}$ & 430 & 360 & 300 & 360 & 2.0 \\
\hline $\begin{array}{l}\text { LW stored for } 3 \text { months and } \\
\text { ozonation for } 60 \mathrm{~min}\end{array}$ & 620 & 520 & 460 & 405 & 2.4 \\
\hline $\begin{array}{l}\text { LW stored for } 6 \text { months and } \\
\text { ozonation for } 30 \mathrm{~min}\end{array}$ & 700 & 600 & 560 & 520 & 3.2 \\
\hline $\begin{array}{l}\text { LW stored for } 6 \text { months and } \\
\text { ozonation for } 60 \mathrm{~min}\end{array}$ & 740 & 640 & 620 & 580 & 3.7 \\
\hline
\end{tabular}


Table 6. Extensogram parameters of RRW ozonated at 80ppm.

\begin{tabular}{|c|c|c|c|c|c|}
\hline \multirow[t]{2}{*}{ Treatment samples } & \multicolumn{3}{|c|}{$\begin{array}{c}\text { Extensibility (E) } \\
\text { (m.m) after three period } \\
\text { fermentation }\end{array}$} & \multirow{2}{*}{$\begin{array}{l}\text { Resistance to } \\
\text { extension (R) } \\
\text { (B.U.): }\end{array}$} & \multirow[t]{2}{*}{$\begin{array}{r}\text { Proportional } \\
\text { number }(\mathbf{R} / \mathrm{E})\end{array}$} \\
\hline & $45 \mathrm{~min}$ & 90 min & $135 \mathrm{~min}$ & & \\
\hline Control & 490 & 400 & 380 & 420 & 2 \\
\hline RRW stored for 3 months & 590 & 520 & 500 & 530 & 3 \\
\hline RRW stored for 6 months & 640 & 480 & 460 & 520 & 2.8 \\
\hline $\begin{array}{l}\text { RRW stored for } 3 \text { months and } \\
\text { ozonation for } 30 \mathrm{~min}\end{array}$ & 640 & 410 & 400 & 480 & 2.7 \\
\hline $\begin{array}{l}\text { RRW stored for } 3 \text { months and } \\
\text { ozonation for } 60 \mathrm{~min}\end{array}$ & 380 & 300 & 220 & 330 & 1.8 \\
\hline $\begin{array}{l}\text { RRW stored for } 6 \text { months and } \\
\text { ozonation for } 30 \mathrm{~min}\end{array}$ & 400 & 280 & 240 & 370 & 1.8 \\
\hline $\begin{array}{l}\text { RRW stored for } 6 \text { months and } \\
\text { ozonation for } 60 \mathrm{~min}\end{array}$ & 420 & 340 & 280 & 380 & 2.4 \\
\hline
\end{tabular}

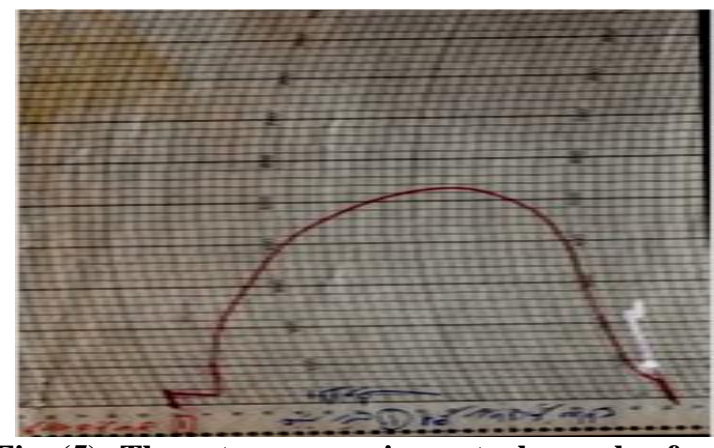

Fig. (5): The extensogram in control sample of RRW

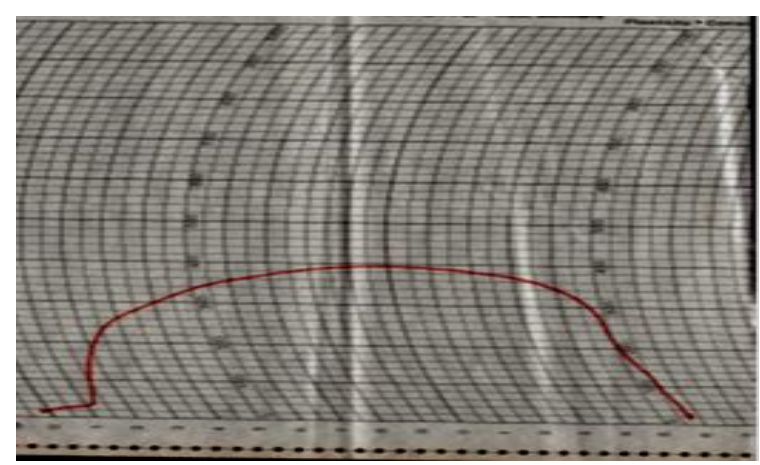

Fig. (7): The extensogram in control sample of $L W$

3. 4. Evaluation of ozonation effect on content of amino acid in wheat grains:

Results in Tables ( 7 and 8 ) show of amino acids content in RRW and LW, after and before ozonation at $80 \mathrm{ppm}$ with exposure time 30 and $60 \mathrm{~min}$. Generally, the results indicated that increase in the amount of amino acids with increasing time of exposure to ozone gas. In case of RRW and LW the content of aspartic acid increased to 0.67 and 0.72 $\mathrm{g} / 100 \mathrm{~g}$ after exposure time 30 and $60 \mathrm{~min}$, respectively if compared with control sample $0.61 \mathrm{~g} / 100 \mathrm{~g}$. Glutamic acid reached to $3.41 \mathrm{~g} / 100 \mathrm{~g}$ after exposure $60 \mathrm{~min}$. While the control sample values $3.03 \mathrm{~g} / 100 \mathrm{~g}$. Tyrosine acid after ozonation at $80 \mathrm{ppm}$ for 30 and $60 \mathrm{~min}$ amounted to 0.43 and $0.46 \mathrm{~g} / 100 \mathrm{~g}$ compared with control sample $0.38 \mathrm{~g} / 100 \mathrm{~g}$. The content of

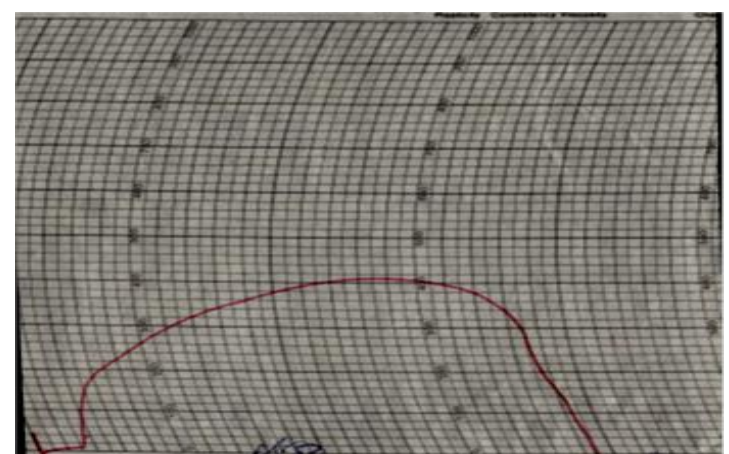

Fig. (6): The extensogram in ozonated sample RRW

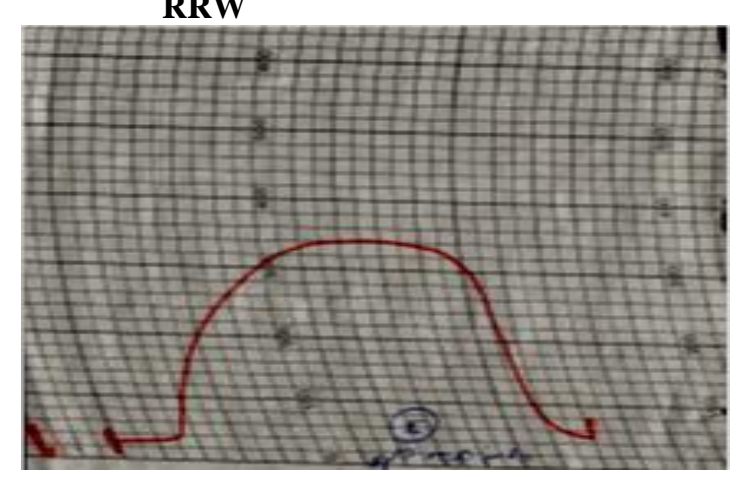

Fig. (8): the extensogram in ozonated sample of LW

cysteine amino acid in control samples 0.30 increased to $0.44 \mathrm{~g} / 100 \mathrm{~g}$ in sample ozonation for $60 \mathrm{~min}$. Local wheat (LW) content of amino acid was presented in Table (8), all amino acids were increased with increased exposure to ozone gas, for example, Tyrosine evaluated to $0.48 \mathrm{~g} / 100 \mathrm{~g}$, as well as lysine, proline and cysteine were $0.35,1.32$ and $0.47 \mathrm{~g} / 100 \mathrm{~g}$, respectively. In the presence of organic compounds, ozone reacts in a variety of complex reactions due to the formation of various reactive species. Ozone reacts with proteins and causes the oxidation of the polypeptide backbone of the protein, peptide bond cleavage, protein- protein cross-linking and a range of amino acid side chain modifications (Kelly and Mudway, 2003). Although all amino acids are potential targets for oxidation by reactive oxygen, the 
major aromatic amino acids tyrosine, tryptophan, phenylalanine, the sulphur containing amino acids cysteine, methionine as well as the aliphatic amino acids arginine, lysine, proline and histidine appear especially sensitive to oxidation. The sequence of amino acids that are condensed in a chain by amide bonds, representing main chain backbone of proteins exhibits negligible or very limited chain scission during ozonation (Uzun et al., 2012). The C-H and S-
$\mathrm{H}$ bonds of alkanes, alkenes, amines and sulfhydryl compounds are attacked by ozone. Amino acids may be attacked directly at the primary amine nitrogen atom or on the R group (Mustafa 1990; Adachi 2001).

The obtained results are in agreement with that obtained by Naitoh (1992), Erdman (1997) and Sandhu et al. (2011).

Table 7. Effect of ozone treatment on the amino acid content of Red Roman Wheat (RRW):

\begin{tabular}{|c|c|c|c|}
\hline \multirow{2}{*}{$\begin{array}{c}\text { Amino acid (g/100 g. } \\
\text { sample) }\end{array}$} & \multicolumn{3}{|c|}{ Exposure time (min) } \\
\hline & $\mathbf{0}$ & 30 & 60 \\
\hline Aspartic & 0.61 & 0.67 & 0.72 \\
\hline Therionine & 0.31 & 0.32 & 0.33 \\
\hline Serine & 0.43 & 0.43 & 0.44 \\
\hline Glutamic & 3.03 & 3.39 & 3.41 \\
\hline Glycine & 0.43 & 0.47 & 0.47 \\
\hline Alanine & 0.46 & 0.46 & 0.46 \\
\hline Valine & 0.54 & 0.51 & 0.52 \\
\hline Isoleucine & 0.35 & 0.38 & 0.41 \\
\hline Leucine & 0.71 & 0.76 & 0.77 \\
\hline Tyrosine & 0.38 & 0.43 & 0.46 \\
\hline Phenylalanine & $\mathbf{0 . 5 3}$ & 0.56 & 0.58 \\
\hline Hisitidine & 0.26 & 0.28 & 0.32 \\
\hline Lysine & 0.31 & 0.34 & 0.35 \\
\hline Arginine & 0.53 & 0.59 & 0.62 \\
\hline Proline & $\mathbf{0 . 9 3}$ & 1.15 & 1.21 \\
\hline Cysteine & 0.30 & 0.39 & 0.44 \\
\hline methionine & 0.36 & 0.22 & 0.24 \\
\hline
\end{tabular}

Table 8. Effect of ozone treatment on the amino acid content of Local wheat (LW).

\begin{tabular}{|c|c|c|c|}
\hline \multirow{2}{*}{$\begin{array}{l}\text { Amino acid (g/100 g. } \\
\text { sample ) }\end{array}$} & \multicolumn{3}{|c|}{ Exposure time (min) } \\
\hline & $\mathbf{0}$ & 30 & 60 \\
\hline Aspartic & 0.71 & 0.77 & 0.79 \\
\hline Therionine & 0.31 & 0.32 & 0.33 \\
\hline Serine & 0.43 & 0.43 & 0.44 \\
\hline Glutamic & 3.33 & 3.41 & 3.52 \\
\hline Glycine & 0.45 & 0.47 & 0.5 \\
\hline Alanine & 0.46 & 0.46 & 0.46 \\
\hline Valine & 0.54 & 0.51 & 0.52 \\
\hline Isoleucine & 0.35 & 0.38 & 0.41 \\
\hline Leucine & 0.71 & 0.76 & 0.77 \\
\hline Tyrosine & $\mathbf{0 . 3 5}$ & $\mathbf{0 . 4 3}$ & 0.48 \\
\hline Phenylalanine & $\mathbf{0 . 5 3}$ & 0.56 & 0.58 \\
\hline Hisitidine & $\mathbf{0 . 2 3}$ & 0.25 & 0.28 \\
\hline Lysine & 0.31 & 0.34 & 0.35 \\
\hline Arginine & 0.53 & 0.59 & 0.62 \\
\hline Proline & 0.97 & 1.25 & 1.32 \\
\hline Cysteine & 0.35 & 0.39 & 0.47 \\
\hline methionine & $\mathbf{0 . 3 3}$ & $\mathbf{0 . 3 0}$ & $\mathbf{0 . 3 3}$ \\
\hline
\end{tabular}

\section{Conclusion}

The obtained results of the present study, it has been concluded that the application of ozonated wheat grain did not significantly alter the chemical composition of LW and RRW after ozonation at 80 ppm for 30 and $60 \mathrm{~min}$. In addition to that the achieved the results indicated that increaments in extensibility, resistance and amount of amino acids with increasing time of exposure to ozone gas has been occurred.

\section{References}


Adachi, D. (2001) Virus inactivation by ozone, Master of Science thesis, University of Toronto.

AOAC. (2000). Association of Official Analytical Chemists. Official methods of analysis $17^{\text {th }}$. Washington D.C., USA.

Dubois, M.; Coste, C.; Despres, A.G.; Efstathiou, T.; Nio, C.; Dumont, E. and Parent-Massin, D. (2006). Safety of Oxygreen, an ozone treatment on wheat grains. Part 2. Is there a substantial equivalence between Oxygreen-treated wheat grains and untreated wheat grains.Food Addit. Contam. 23(1): 1-15.

El-Desouky, T.A.; Sharoba, A.M.A.; El-Desouky, A.I.; El-Mansy, H.A. and Naguib, K. (2012a). Effect of Ozone Gas on Degradation of Aflatoxin B1 and Aspergillus Flavus Fungal. J Environment Analytic Toxicol 2:128. doi:10.4172/21610525.1000128.

El-Desouky, T.A.; Sharoba, A.M.A.; El-Desouky, A.I.; El-Mansy, H.A. and Naguib K. (2012b). Evaluation of ozone gas as an anti-aflatoxin B1 in wheat grains during storage. Journal of Agroalimentary Processes and Technologies, 19(1): 13-19.

El-Desouky, T.A.; Sharoba, A.M.A.; El-Desouky, A.I.; El-Mansy, H.A. and Naguib, K. (2013). Effect of ozonation of wheat grain on quality bread factory. Journal of Agroalimentary Processes and Technologies, 19(1): 1-9.

El-Desouky, T.A.; Sharoba, A.M.A.; El-Desouky, A.I.; El-Mansy, H.A. and Naguib, K. (2017). Biological and Histopathological Evaluations of Using Ozone Gas in Decontamination of AflatoxinB1 in Wheat Grains. MOJ Toxicol 3(3): 00056. DOI: 10.15406/mojt.2017.03.00056.

Erdman, J.W.Jr (1997). Nutrient impact (of ozone contact with foods), in EPRI (1997) Expert Panel Report: Evaluation of the History and Safety of Ozone in Processing Food for Human Consumption, Vol. 1: Executive Summary, Palo Alto,CA: Electric Power Research Institute, Final Report, TR-108026-VI-4827, Chapter 5).

Gupta, R.B.; Khan, K. and MacRitchie, F. (1993). Biochemical basis of flour properties in bread wheat. I. Effects of variation in the quality and size distribution of polymeric protein. Cereal Science, 18: $23-41$

Guzel-Seydim, Z.B.; Greene, A.K. and Seydim, A.C. (2004). Use of ozone in the food industry. Lebensmittel- wissenschaft und-Technologie, 37 : 453-460.

Hoseney, R.C. (1994). Principles of cereal science and technology. $2^{\text {nd }}$ ed, American Assoc. Cereal Chem. Inc. St. Paul, Minnesota. USA

Hussein, A.M.S.; Kamil, M.M. and Ragab, G.H. (2010). Technological Properties of some Egyptian New Wheat Varieties. Journal of American Science, 6(11): 688-699.
Ibanoglu, S. (2002). Wheat washing with ozonated water: effects on selected flour

properties. International Journal of Food Science and Technology. 37: 579-584.

Kells, S.A.; Mason. L.J.; Maier, D.E. and Woleshok, C.P. (2001). Efficacy and fumigation characteristics of ozone in stored maize. Journal of Stored Products Research, 37: 371-382.

Kelly, F.J. and Mudway, I.S. (2003). Protein oxidation at the air lung interface. Amino Acids, 25: 375-396.

Kim, J.G.; Yousef, A.E. and Dave, S. (1999). Application of ozone for enhancing the microbiological safety and quality of foods: a review. Journal of Food Protection, 62(9): 10711087.

Mendez, F.; Maier, D.E.; Mason, L.J. and Woloshuk, C.P. (2003). Penetration of ozone into columns of stored grains and effects on chemical composition and processing performance. J. Stored Prod. Res., 39: 33.

Moore, s.; Spachman , D. H. and Stein,W. (1958) Chromatography of amino acid on sulphonated polystyiene resins , Anal. Chem., 30: 1185-1190

Mustafa, M.G. (1990). Biochemical basis of ozone toxicity, Free Radical Biology and Medicine, 9: 245-65.

Naito, S. (1990). Effect of ozone treatment on the rheological properties of wheat flour. Journal of the Japanese Society for Food Science and Technology, 37(10): 810-813.

Naitoh, S. (1992) Studies on the application of ozone in food processing: mutagenicity of ozone-treated amino acids and saccharides, J Antibact Antifung Agents, 20(7): 365-72.

Paul, J.S. (2005). Comparative effects of two ozonation treatments on wheat flour technological properties.ph.D thesis, Kansas state university, France.

Samati, P.M. and Rajagopal, M.P. (1996). Fundamentals of food and nutrition 3 rd edition, New Delhi, India.

Sandhu, H.; Manthey, F. and Simsek, S. (2011). Quality of bread made from ozonated wheat (Triticum aestivum L.) flour. Journal Science of Food and Agriculture, 91: 1576-1584.

Sandhu, H.; Manthey, F. and Simsek, S. (2012). Ozone gas affects physical and chemical properties of wheat (Triticum aestivum L.) starch. Carbohydrate Polymers, 87: 1261- 1268.

Selim, A.H. (2000). Evaluation of some heat tolerant wheat germplasms for yield and yield quality. Ph.D. Thesis, Ain Shams University, Egypt.

Takasaki, S.; Kato, Y.; Murata, M.; Homma, S. and Kawakishi, S. (2005). Effects of peroxides and hydrogen peroxide on the dityrosine formation and the mixing characteristics of wheat-flour dough. Bioscience Biotechnology and Biochemistry, 69 1686-1692. 
Uzun, H.; Ibanoglu, E.; Catal, H. and Ibanoglu, S. (2012). Effects of ozone on functional properties of proteins. Food Chemistry 134: 647-654.

Violleau , F.; Pernot, A.G. and Sure, O. (2012) Effect of Oxygreen wheat ozonation process on bread dough quality and protein solubility. Journal of Cereal Science, 55:392-396. 